\title{
EFFECT OF PARTICIPATORY BUDGETING ON MANAGER PERFORMANCE: GOAL COMMITMENT AND MOTIVATION AS MODERATING VARIABLE
}

\author{
Eko Hariyanto \\ Muhammadiyah University of Purwokerto \\ ekoh0361@gmail.com
}

\begin{abstract}
This study aims, first examine the effect of participative budget on manager's performance, and to examine the indirect effect of goal commitment and motivation as intervening variables. The data collected by survey questionnaires. Fifty eight-level managers, from state owned enterprises in Banyumas, Purbalingga, Cilacap and Banjarnegara, who were randomly participated in this research. Partial least square (PLS) to run a structural equation modeling (SEM) technique was employed to analyze the data. The finding showed that participative budget did not significantly influence manager's performance. Participative budget increase the managers' performance through the increase in goal commitment, which has a significant, positive effect on motivation. Furthermore, motivation has a significant, positive effect on managers' performance.
\end{abstract}

Key words: participative budget, goal commitment, motivation, performance manager, goal setting theory, the state owned enterprise.

\section{INTRODUCTION}

Budget or the budget is the operationalization of corporate strategy in achieving the goals. The ability in budgeting or properly conducting should be made by way of bottom-up and engage the budget user. The budget is also a management tool for control, coordination, communication, job evaluation, and motivation [1].

Manager's behavior is influenced primarily by psychological factors. Social factors, motivational, cognitive and psychological factors that affect managers in preparing and running the budget.

There are some psychological factors that affect humans in the budget; this leads a lot of researchers to explore such factor. Argyris [2] examines how the budget process can affect their performance. The study then led to other studies of behavioral aspects of budgeting process, for example, leadership style [3], task uncertainty [4], the behavior of managers [1], motivational influences (Latham and Steele, 1983), perceptions of justice (Wenzel, 2002) and commitment to the goals. The studies above give the impression that managers consider the budget side of human behavior has a major influence on the achievement of budget targets in the budgeting process.

From the results of research [5], this study uses the psychological factors: motivation, and commitment to the goal. The variables are intervening variables in the relationship between participatory budgeting and performance managers.

With the above descriptions, researchers are encouraged to examine the influence of participatory budgeting on the performance of managers in corporate enterprises in the district of Banyumas, Purbalingga, Cilacap and Banjarnegara.

\section{METHOD}

Population in this research are all middle managers in the company's Regional Owned Enterprises (enterprises) in Banyumas, Purbalingga, Cilacap, and Banjarnegara. Total population until the year 2017 is the 24 public enterprises in which there are 96 managers who had been listed as a sampling frame, then sent as a respondent. Participation is the budget manager or subordinate involvement in the budgetary process. To measure the participation of the budget, here, an instrument developed by Milani [6] will be used.

Goal commitment is defined as a person of determination to achieve goals [7]. The level of commitment to the goals (goal commitment) of managers is measured by using a three-item questions, based on Latham and Steele [8].

Motivation by Robin defined as a process that produces an intensity, direction and persistence of individual in an attempt to achieve a goal. Motivation in this study measured by instruments developed by Lawer et al, but in this study using a scale of 5 points.

Managerial performance include proficiency level managers in implementing management activities that include planning, organizing, investigations, regulation, 
negotiation, representation, monitoring and evaluation. Managerial performance measurement will be assessed by using an instrument developed by Mahoney et. al. [9].

Outer measurement model or the model is to analyze the relationship between each block indicator (manifest) with latent variable (construct) [10]. To analyze the outer model can be seen from: convergent validity, discriminant validity, and Composite reliability.

\section{RESULT}

\section{Participatory Budgeting influence Directly To Performance Manager}

The research hypothesis states that participatory budgeting has a positive effect on the performance of managers. From the test results, with PLS, it can be seen that the influence of participatory budgeting is not significant to the performance of managers. The results of this test is not consistent with the findings of [1], [3], [11], [12]. However, this research provides the same results with the results of research [6], [13]. In a study [6] states that participatory budgeting manager's performance is expected to increase because according to the theory of goal setting [7] that when a goal was made jointly, then each will feel a sense of responsibility to achieve, thus increasing performance.

Descriptive research results noted that overall participation in budgeting in the public enterprises on average have 3.6 on the scale of 5 points. Thus, the level of participation in budgeting in the public enterprises companies in Banyumas, Cilacap, Purbalingga and Banjarnegara in the category was. Participation in the case of managers without being asked to propose opinions, requests or suggestions are still below the number 3 . So is participation in the employer requested the opinion of the manager when the budget was being made. Whereas in the case of participation in budget formulation, the reason for revising the budget and contributions to the budget managers have on the number 3 . This clearly illustrates that the factors are influential leaders of the budget preparation.

\section{The influence of Participatory Budgeting on goal commitment}

Participatory budgeting have a significant effect on goals commitment and having a positive relationship. The amount of correlation between goal commitment to participatory budgeting is at 0.250 goals, which in this case includes a low correlation.

These support the results of research [14], [15]. This means that the higher the level of participation in the preparation of the budget will increase commitment to the goal.

In the participatory budgeting, one of the most prominent indicator is whether employers often ask the opinion of the manager when the budget proposals being made. This shows that your employer is still dominant in the budgeting. While the commitment to the objective indicator of the importance of efforts to achieve budget is the responsibility of managers is the most dominant indicator. Thus, it can be said that the more opinion being asked, the managers will increasingly seek to achieve a budget they are responsible.

\section{The influence of goal Commitment on Manager Performance}

Goal Commitment was positive affect on the manager's performance can be seen by comparing the value of t-statistic with $\mathrm{t}$-table values. With a $5 \%$ error rate, the value of $\mathrm{t}$ statistics smaller than 1.96 , which means not significant. Correlation between commitments to the goal with a manager's performance is 0315 . Here, the correlation included as low correlation relationship.

Commitment is used to demonstrate the extent of business objectives, all the time (over times) to the original target and the absence of a desire to remove or reduce the target. Therefore, it can be interpreted that the commitment to the objectives of a company's managers are willing to achieve goals, it is important to achieving business goals and have a great desire to achieve it.

However, the results of this study do not support the research [15], which states that the commitment to the goals affects manager's performance. Contrastingly, this study supports the study conducted by [14] that a commitment to purpose not directly affects the manager's performance. In addition, Murray, in 1990, suggested "If an individual becomes committed to a given goal, it will influence the individual's actions and performance". The theory of goal setting and performance; there is a direct influence from the motivational factors, whereas cognitive factors influence indirectly [7]. In this case, a commitment to the goal does not directly affect the performance of managers, but can affect their motivation.

\section{The influence of Participatory Budgeting to Motivation}

From the results, it can be seen that participatory budgeting is not a significant effect on motivation. By looking at statistics of 1.212 , it can be concluded with a 5\% error rate is not significant because it is smaller than 1.96.

Interpretation of the results is that the higher the participation rate, the higher the motivation of managers to achieve goals.

\section{The influence of motivation on manager's performance}

From the six hypotheses, it can be concluded that the positive motivational effect on the performance of managers. Motivation, by Robin defined as a process that produces an intensity, direction and persistence of individual in an attempt to stigmatize one purpose. While others say the definition of motivation is a degree of one's individual wants and trying to do the job well [16]. 
Interpretation of the results of this study is that the company managers are motivated because they have the commitment to achieve a goal as well as the sensitive issue of budgeting.

\section{Influence of Budgeting Participation to Manager's Performance through Goals Commitment and Motivation}

The influence of Budgeting Participation to Performance Manager's through commitment to the goals and motivations can be explained in the following relationship:

Participatory budgeting $\rightarrow$ Commitment to goals $\rightarrow$ Motivation $\rightarrow$ Performance Managers

For the influence of participatory budgeting to the commitments outlined in the objectives, namely participatory budgeting have a significant effect of commitment on the goal.

\section{The Influence of Goal Commitment to Motivation}

The data reflect that commitment has a positive effect on the purpose of motivation. From the results of hypothesis, it can be explained that the commitment is expected if the goal is committed to the goal will increase motivation.

\section{CONCLUSION}

Participatory budgeting does not directly affect the manager's performance, hence this indicates that there are mediating variables in the relationship. Participatory budgeting positively related to the performance of managers.

Higher levels of participation in the budget will increase the commitment to the goal. This result gives the meaning that the managers invited along on the budget and led by top managers (superiors). Such condition is often helps to increase the excess of the managers and suggest new ways to accomplish the task, it will also increase the commitment of the managers in an effort to achieve budget as their responsibility.

Participatory budgeting has a significant positive effect on commitment to the goal. Commitment to the goal does not directly affect the performance of managers. This indicates that the higher the level of participation will increase the commitment to the goal. While the increasing commitment to the purposes not directly improve the performance of managers.

Participatory budgeting affect motivation but not significant, while motivation significantly gives positive impact on the performance of managers. The greatest influence of motivation is the motivation to work hard for reaching high productivity. Thus, it can be concluded that by motivating managers to work hard and have the expectation of higher productivity, it will improve the performance of managers.
Commitment to the objectives and significant positive impact on motivation. The greatest influence of commitment to the goal is the attempt to achieve a budget that is the responsibility of managers. This means that if the efforts to achieve a budget increase, the responsibility of managers will increase as well.

\section{REFERENCES}

[1] Merchant KA , "The Design of Corporate Budgeting System: Influences on Managerial Behavior and Performance", The Accounting Review, No.4, 1981.

[2] Argyris, The Impact of budgets on People, New York: Controllership Foundation, Inc, 1952.

[3] Brownell, P."The Role of Accounting Data in Performance Evaluation, Budgetary Participation, and Organizational Effectiveness", Journal of Accounting Research, Volume 20 No.1 Spring, 1982.

[4] Hirst Court, "The Effects of Setting Budget Goals and Task Uncertainty on Performance: A Theoretical Analysis", The Accounting Review, October, p 778784, 1987.

[5] Dennis Murray, "The Performance Effects of Participative Budgeting: An Integration of Intervening and moderating Variables", Behavioral Risearch in Accounting, Volume 2, 1990.

[6] Milani, K.,"The Relationship of Participation in Budget-Setting to Industrial Supervisor Performance and Attitudes: A Field Study", The Accounting Review, April, (pp. 274-284), 1975.

[7] Edwin A. Locke, and Gary P. Latham, A Theory of Goal Setting \& Task Performance, Englewood Cliffs: Prentice-Hall, Inc, 1990.

[8] Latham, GP, and TP Steele, "The motivational effects of participation versus goal-setting on performance, Academy of Management 26: p. 406-407, 1983.

[9] Mahoney, T., TH Jerdee, and SJCarroll,Development of Managerial Performance: A Research Approach, Cincinnati, OH: South-Western Publishing Company, 1963.

[10] Imam Ghozali, Structure Equation Modeling: Alternative Method with Partial Least Square, the first edition, Semarang: Badan Penerbit Universitas Diponegoro, 2006.

[11] Nur Indriantoro, The effect of Participative Budgeting on Job Performance and Job Satisfaction with Locus of Control and Cultural Dimensions as moderating Variables, PhD dissertation, University of Kentucky, USA, 1993.

[12] Frucot, V and Shearon WT, "Budgetary Participation, Locus of Control, and Mexican managerial Performance and Job Satisfaction", The Accounting Review, January, (pp. 80-89), 1991.

$\mathrm{V}$ and Shearon WT, "Leadership Style, Budgetary Participation and Managerial Behaviors", Accounting, 
Organizations and Society, September. Hal. 307-321, 1983.

V and Shearon WT, "A Field Study Examination of Budgetary Participation and Locus of Control", The Accounting Review, Vol. LVII, no. 4, October, (pp. 766-777), 1982.

[13] Brwnell And Hirst, M., "Reliance on Accounting Information, Budgetary Participation, and Task Uncertainty", Journal of accounting Research, Vol 24, (pp. 241-249), 1986.

[14] Vincent K. Kar Sun Chong and Chong ,"Budget Goal Commitment, and Informational Effects of Budget
Participation on Performance: A Structural Equation Modeling Approach", Behavioral Research in Accounting, Volume 14, pg 65, 2002.

[15] Kristin Wentzel, "The Influence of Fairness Perception and Goal Commitment on Managers' Performance in a Budgeting Setting", Behavioral Research in Accounting, Volume 14, pg 247, 2002.

[16] Mitchael C. Jensen, William H. Mekling, Divisional Performance Measurement, Social Scienence Research Network (SSRN) Electronic Library at: ,http://papers.ssrn.com./ABSTRACT ID=94109, 1998. 